\title{
0 historykach medycyny i zakładach naukowych pierwszej połowy lat 50 . XX w. w świetle sprawozdania Ministerstwa Zdrowia
}

\begin{abstract}
On historians of medicine and research institutes of the first half of the 1950s in the light of the report of the Ministry of Health
\end{abstract}

\begin{abstract}
Summary
The article discusses the issue of the perception of the academic milieu of medical historians through the prism of the new post-war reality of the early 1950s. The author, based on the document - a report on a tour of scientific institutions by Dr. A. Smoluchowski - presents the then way of assessing medical historians, which to a large extent it depended on their individual views and attitude to the new Marxist ideology. In the end, the image of the community of Polish medical historians of the analyzed period turned out to be not the most interesting. It was supposed to be very conflicted, full of prejudices, blurring, disagreements, very attached to the pre-war way of practicing history, with little valuable achievements. How was it really? What could have been the cause of such an opinion? The author of the article tries to find an answer to these and other questions.
\end{abstract}

Słowa kluczowe: historia medycyny, zakłady historii medycyny, pracownicy naukowi, lata 50. XX w.

Keywords: history of medicine, medical history units, researchers, 1950s 
Po zakończeniu wojny zakłady historii medycyny stanowiące integralną część wydziałów lekarskich, podobnie jak inne placówki naukowe uczelni wyższych, borykały się z wieloma problemami natury materialnej, ale przede wszystkim personalnej. Powszechne były na każdej uczelni niedobory lokalowe, o czym wielokrotnie wspominano w rocznych sprawozdaniach, pisano m.in. o konieczności przeprowadzenia remontów tego czy innego pomieszczenia, o niedoborze chemikaliów czy odczynników niezbędnych do prowadzenia działalności naukowej, nie wspominając już o braku podstawowej literatury naukowej. Uskarżano się także na tzw. szczupłość sal wykładowych, pisano o braku szatni itp., tzw. bolączek było mnóstwo. W przypadku zakładów historii medycyny niedobory wydawały się jeszcze bardziej odczuwalne. Brakowało już nie tylko wyasygnowanych dla tego typu jednostek naukowych pomieszczeń, ale także wyposażenie tych przyznanych prezentowało się bardzo ubogo. Kilka stołów i krzeseł stanowiło zazwyczaj całość. Stan podręcznych bibliotek czy raczej księgozbiorów przyzakładowych, zwłaszcza w przypadku zakładów historii medycyny, również był niedostateczny, choć - co należy podkreślić - bardzo zróżnicowany, o czym w dalszej części pracy.

Problematyka ta jak dotąd jest mało opracowana. Zazwyczaj analizie poddawany jest dorobek naukowy historyków medycyny. Na uwagę zasługuje tutaj m.in. artykuł Zbigniewa Jastrzębowskiego i Tadeusza Srogosza ${ }^{1}$, poruszający kwestię polskiej szkoły filozofii medycyny W zetknięciu z marksizmem. Podobną tematyką zajął się Michał Musielak $^{2}$. Z kolei Jaromir Jeszke ${ }^{3}$ poszukiwał paradygmatu w polskiej historiografii medycznej. Także Magdalena Paciorek ${ }^{4} \mathrm{w}$ artykule nt. posiedzeń Komisji Historii Medycyny z lat 1952-1956 nawiązywała do środowiska historyków medycyny. Jednak sprawa ich wizerunku jako grupy naukowców zajmujących się historią i filozofią nauki, a zatem w dużym stopniu będących w opozycji przeciwko rządzącym, nie była dotąd badana.

Źródłem badań do niniejszego opracowania są m.in. sprawozdania uczelniane kierowników zakładów i katedr historii medycyny zdepo-

${ }^{1}$ Z. Jastrzębowski, T. Srogosz, Polska szkoła filozofii medycyny a marksizm, „Medycyna Nowożytna" 1994, z. 1-2, s. 61-68.

${ }_{2}$ M. Musielak, Adam Wrzosek, [w:] M. Musielak, J. zamojski (red.), Polska szkoła filozofii medycyny. Przedstawiciele i wybrane teksty źródłowe, Poznań 2010.

3 J. Jeszke, W poszukiwaniu polskiej historiografii medycznej, Poznań 2000; idem, Mity polskiej historiografii nauki, Warszawa 2007.

${ }_{4}$ M. Paciorek, Działalność Komisji Historii Nauk Medycznych przy Radzie Naukowej Ministerstwa Zdrowia w latach 1952-1956 w świetle dokumentów Archiwów Akt Nowych, „Medycyna Nowożytna” 2019, z. 1, s. 141-160. 
nowane w zasobach uczelnianych archiwów, ale przede wszystkim sprawozdanie z 1950 r. z objazdu naukowego polskich ośrodków naukowych, sporządzone przez dr. Adama Smoluchowskiego ${ }^{5} \mathrm{w}$ przeddzień rozpoczęcia I Kongresu Nauki Polskiej, przechowywane w zbiorach AAN $^{6}$. Należy nadmienić, że wspomniana inspekcja zakładów historii medycyny zaplanowana została m.in. w celu nawiązania ewentualnych kontaktów z osobami parającymi się historią medycyny, w przyszłości potencjalnie zatrudnionych w Dziale Badań nad Historią Medycyny zorganizowanym przy Państwowej Szkole Higieny $(\mathrm{PSH})^{7}$. Kierownikiem tego Działu, podległego PSH, a następnie Ministerstwu Zdrowia, był wspomniany dr Adam Smoluchowski.

Ważną sprawą jest też uświadomienie sobie, w jakim celu powołano ów Dział przy PSH. W treści dokumentu zdeponowanego w zbiorach AAN pisano m.in., że „głównym zadaniem działu jest prowadzenie i kierowanie badaniami naukowymi $\mathrm{z}$ historii medycyny $\mathrm{w}$ oparciu o naukowe metody pracy, tj. dialektycznie i zgodnie $\mathrm{z}$ materializmem historycznym $^{8}$. Zdanie to już samo $\mathrm{w}$ sobie wyjaśnia bardzo wiele. $\mathrm{W}$ duchu nowych przemian zachodzących w kraju i społeczeństwie tworzony będzie zatem wizerunek ówczesnego środowiska historyków medycyny.

Autorem był wspomniany dr Adam Smoluchowski (1914-2011) lekarz dermatolog, wychowanek i pracownik naukowy Uniwersytetu Jagiellońskiego, a następnie założyciel Biblioteki Centrum Wyszkolenia Sanitarnego WP w Łodzi oraz kierownik Wydziału Historii Medycyny w Lekarskim Instytucie Naukowo-Wydawniczym. W badanym okresie zdeklarowany członek PZPR ${ }^{9}$. Przynależność ta, jak można przypuszczać, okazała się bardzo pomocna w karierze urzędniczej lekarza, zwłaszcza w okresie pierwszej połowy lat 50 . XX w. Z racji wcześniej zajmowanych stanowisk w Zakładzie Historii Medycyny w Krakowie, młodszego asystenta, asystenta, a następnie starszego asystenta, w omawianym roku zlecono Smoluchowskiemu dokonanie objazdu naukowego po istniejących zakładach działających przy ówczesnych akademiach lekarskich.

Rzeczą istotną dla zrozumienia ówczesnej sytuacji zakładów jest również fakt zawieszenia $\mathrm{z}$ dniem 23 grudnia $1948 \mathrm{r}$. zajęć $\mathrm{z}$ historii medycyny. Zarządzenie to, wydane przez ówczesne Ministerstwo Oświaty,

\footnotetext{
${ }^{5}$ Archiwum Akt Nowych (dalej: AAN), Ministerstwo Zdrowia (MZ), sygn. 21/1.

${ }^{6}$ I Kongres Nauki Polskiej - 29 VI-2 VII 1951 r.

7 AAN, MZ, sygn. 5/1, k. 4-11.

${ }^{8}$ Ibidem, k. 4.

${ }^{9}$ AAN, MZ, sygn. 21/1, k. 33.
} 
było rezultatem nowej polityki władz komunistycznych, zmierzającej m.in. do przebudowy społeczeństwa polskiego pod względem strukturalnym oraz ideologicznym. W odniesieniu do wykładowców historii medycyny przynależnych do warstwy inteligenckiej zastrzeżenia wzbudzać mogły nie tylko poszczególne osoby, ale przede wszystkim treści wykładów przekazywane młodym pokoleniom lekarzy. W nowej rzeczywistości lat 50. w opinii ówczesnych władz należało zweryfikować dotychczasowy sposób uprawiania historii medycyny i „wskazać” właściwy kierunek badań. W okresie realnego socjalizmu historia medycyny miała za zadanie m.in. wykazać postępowość zgodnie z zasadami materializmu dialektycznego i historycznego, wystrzegać się kosmopolityzmu i wstecznictwa, opracowywać przeszłość polskiej medycyny ze stanowiska socjologicznego, ze szczególnym uwzględnieniem organizacji służby zdrowia od czasów najdawniejszych, wreszcie też, a może przede wszystkim, w badaniach naukowych należało opierać się na doświadczeniach i badaniach budownictwa socjalistycznego służby zdrowia $\mathrm{w}$ Związku Radzieckim ${ }^{10}$. Zastosowanie powyższych wytycznych czy też określenie możliwości dostosowania się samego środowiska historyków medycyny do nowej sytuacji wymagało przyjrzenia się bliżej zarówno samemu środowisku, jak i jego warunkom pracy, a przede wszystkim istnieniu bazy źródłowej.

\section{Warunki materialne powojennych zakładów historii medycyny}

Jak już wspomniano, sytuacja materialna zakładów historii medycyny w powojennej rzeczywistości przedstawiała się wręcz katastrofalnie. We wszystkich tego typu placówkach odczuwano braki zarówno pomieszczeń, jak i podstawowego wyposażenia. Najlepiej przedstawiała się sytuacja na Uniwersytecie Jagiellońskim, choć i tam wojna i okupacja pozostawiła swoje ślady.

W jednym z pierwszych sprawozdań z września 1945 r. na temat działalności krakowskiego Zakładu Historii Medycyny prof. Władysław Szumowski (1875-1954), ówczesny kierownik zakładu, przedstawiał koleje losów budynku pozyskanego dla zakładu w 1939 r., który po wybuchu wojny przejęło wojsko niemieckie, urządzając w nim na parterze natryski dla żołnierzy. Sprzęt i wszelkiego typu urządzenia zostały wówczas porozrzucane po całym Krakowie. W 1944 r. budynek zakładu stał się częścią składową tzw. szpitala warszawskiego utwo-

${ }^{10}$ AAN, MZ, sygn. 5/17, k. 261. 
rzonego na terenie Krakowa. Po zakończeniu działań wojennych, jak pisał prof. Szumowski, „obejmowanie budynku z powrotem w $1945 \mathrm{r}$. trwało kilka miesięcy (...). Ostateczne oddanie całego budynku nastąpiło we wrześniu 1945 r. Przywrócenie budynku do dawnego stanu jeszcze potrwa jakiś czas (...) wiele rzeczy zginęło bezpowrotnie, które okupanci bądź powywozili, bądź porąbali na opał. Na szczęście bogaty księgozbiór (7 tys. tomów) i archiwum ocalały i są w porządku (...)"11. W tej oto lepszej sytuacji znalazł się właśnie krakowski Zakład Historii Medycyny, nie tracąc cennych zbiorów. Przywrócenie budynku do stanu względnej używalności trwało jednak do połowy roku 1946 r., kiedy usunięto natryski i wyremontowano sale. Wówczas to sprowadzono z Biblioteki Jagiellońskiej księgozbiór, resztę mebli oraz ocalałych okazów muzealnych ${ }^{12}$. By jeszcze bardziej przybliżyć klimat owych czasów, należy dodać, że ów remont nie był, jak mogłoby się wydawać, remontem we współczesnym tego słowa znaczeniu. Jak się okazało, problemem zakładu była obecność pluskiew, które zdołano usunąć dopiero $\mathrm{w}$ drugim powojennym roku akademickim. Trudności natury materialnej towarzyszyły zakładowi jeszcze przez kolejne lata. Dotacje i wszelka pomoc okazywały się zazwyczaj niedostateczne. Nadal trzeba było dokonywać remontów, dokupować szafy i regały na książki. „Na właściwe pomoce naukowe, książki i czasopisma nie było już funduszów"13. W kolejnym roku akademickim 1946/1947 zmagano się z przeciekającym dachem zakładu. Szumowski pisał: „na wiosnę 1947 r. zaczął tajać śnieg na dachu, cały strych był zlany i sufity przeciekały, trzeba było na gwałt dach reperować"14. Pomimo tych trosk i kłopotów prace naukowo-dydaktyczne prowadzono systematycznie. Wykłady dla znacznej liczby - ok. 300 - studentów w pierwszym roku prowadzono w sali Anatomii Opisowej przy ul. Kopernika 12. Także w kolejnych latach liczba słuchaczy nie malała. W 1947 r. w Zakładzie na parterze po raz pierwszy urządzono wystawę, adresowaną do studentów I roku medycyny, pt. „Jak wygląda medycyna”, która cieszyła się sporym powodzeniem wśród słuchaczy. Także na pierwszym piętrze zorganizowano wówczas czytelnię dla medyków.

${ }_{11}$ Archiwum Uniwersytetu Jagiellońskiego, sygn. SIII-32, k. 12. Sprawozdanie z działalności Zakładu Historii Medycyny rok 1945.

${ }_{12}$ AUJ, sygn. SIII- 33, k. 12, Sprawozdanie z działalności Zakładu Historii Medycyny za rok 1945/1946.

${ }^{13}$ Ibidem.

${ }^{14}$ AUJ, sygn. SIII-34, k. 20, Sprawozdanie z działalności zakładu historii medycyny Uniwersytetu Jagiellońskiego za rok 1946/1947. 
Stałym problemem kierownictwa był też brak odpowiedniej liczby personelu. W 1945 r. w Zakładzie zatrudniano zaledwie trzy osoby: kierownika zakładu, młodszego asystenta oraz jednego woźnego. Rok później, jak wynika z kolejnego sprawozdania, sprawa ta nieco uległa poprawie, gdyż oprócz prof. Władysława Szumowskiego i lek. Adama Smoluchowskiego - asystenta etatowego, zatrudniony był też w charakterze wolontariusza dr Zbigniew Kukulski (1908-1971) ${ }^{15}$. Obecny był również Witołd Ziembicki (1874-1950) ${ }^{16}$ - przedwojenny kierownik lwowskiego Zakładu Historii Medycyny, który w zastępstwie za Szumowskiego prowadził w Krakowie wykłady dla studentów. Trwało to jednak krótko, gdyż w 1946 r. przeniósł się do Wrocławia. Tymczasem w Krakowie w 1947 r. Smoluchowskiego oddelegowano do wojska. Rok później kierownictwo zakładu po przechodzącym na emeryturę prof. Szumowskim objął wspomniany Zbigniew Kukulski ${ }^{17}$. Do pomocy przydzielono studenta medycyny Kazimierza Lubińskiego, przyjętego do zakładu na stanowisko młodszego asystenta.

Tak w dużym skrócie przedstawiały się problemy materialne najstarszego w Polsce zakładu historii medycyny. Na temat pozostałych zakładów w Warszawie, Wrocławiu, Łodzi, Gdańsku, Poznaniu czy Lublinie zachowało się niewiele informacji.

Powróćmy jednak do wspomnianego dokumentu z roku 1950, kiedy to, jak wynika z przekazu, przedwojenne zakłady historii medycyny przetrwały próbę czasu, choć rozmiar zniszczeń i poniesionych strat był dość zróżnicowany.

Gdański Zakład Historii Medycyny, kierowany od 1946 r. przez prof. Tadeusza Bilikiewicza, miesił się na parterze Kliniki Chorób Psychicznych na terenie szpitala przy ul. Dębinki $7 \mathrm{nr} 25$, a od marca 1947 r. uzyskał lokal na terenie II Kliniki Chorób Wewnętrznych prof. Górskiego na trzecim piętrze. 7 października 1948 r. Ministerstwo Oświaty nie wyraziło zgody na dalszą działalność dydaktyczno-naukową i z dniem 30 czerwca 1949 r. jednostka przesłała istniećc ${ }^{18}$. Jego niewielka, bo licząca ok. 250 pozycji książkowych, biblioteka umieszczona została wówczas na terenie Kliniki Chorób Wewnętrznych.

${ }^{15}$ M. Skulimowski, Doc. dr med. Zbigniew Kukulski (1908-1971), „Archiwum Historii Medycyny" 1972, z. 1/2, s. 185-188, http://cybra.lodz.pl/Content/7060/334_ForumNr_10ForumNr10.pdf [dostęp: 10.12.2021].

${ }^{16}$ http://cybra.lodz.pl/Content/5911/625-644.pdf [dostęp: 10.12.2021].

17 AUJ, sygn. SIII-35, k. 33-34.

${ }_{18}$ E. Sieńkowski, Dzieje Akademii Medycznej w Gdańsku 1945-1995, Gdańsk 1995, s. 63; Z. Machaliński, Wokót genezy i początków Akademii Medycznej w Gdańsku, Gdańsk 1998, s. 126-127. 
Doktorantów z przedmiotu historii medycyny egzaminować miał prof. Tadeusz Bilikiewicz. Zespół tworzyli wówczas m.in. Klementyna Bilikiewiczowa, Stanisław Sterkowicz oraz Jan Ossowicki.

W zdecydowanie gorszych warunkach znalazł się stosunkowo młody Zakład Historii Medycyny w Lublinie, który - jak wynika z raportu - uległ likwidacji znacznie wcześniej, bo już w 1946 r. z powodu „fatalnych warunków lokalowych" ${ }^{19}$. Pisano o ciemnym, wilgotnym, nieopalanym pokoju, który stanowić miał wówczas całość zakładu. Po jego likwidacji zarówno meble, jak i inwentarz, w tym również 200 tytułów książek, przekazane zostały do Zakładu Mikrobiologii Lekarskiej w Lublinie przy ul. Lubartowskiej 57. Na temat tamtejszych zbiorów bibliotecznych zakładu pisano „Biblioteka była chaotyczną zbieraniną nie mającą żadnej wartości”" ${ }^{20}$. Dwuosobowy zespół, składający się z prof. Ludwika Zembrzuskiego i starszego asystenta Stanisława Grodzkiego, bardzo szybko uległ likwidacji. Profesor Zembrzuski, nie mogąc uzyskać mieszkania w Lublinie, przeniósł się do Bydgoszczy, Grodzki zaś został dyrektorem Miejskiej Biblioteki. Zachowaną spuścizną zaopiekował się prof. Stein. Wykłady z historii farmacji prowadziła wówczas prof. Z. Kalinowska.

Kolejny Zakład Historii Medycyny, działający w ramach Wydziału Lekarskiego Akademii Lekarskiej w Łodzi, mieścił się w jednym, dużym pokoju przy ul. Narutowicza 60. Jego wyposażenie stanowić miało wówczas biurko, stół oraz - jak opisywano w sprawozdaniu - kilkadziesiąt krzeseł. Biblioteka składała się z 700 tomów pozycji książkowych. O jej wartości pisano wówczas następująco: „księgozbiór bardzo szczupły i zupełnie niekompletny nie stanowiący najmniejszego warsztatu pracy naukowej"21.

Obsadę personalną zakładu tworzyły wówczas dwie osoby: kierownik - prof. Jan Szmurło oraz starszy asystent Józef Dziadek. Po zawieszeniu wykładów $\mathrm{z}$ historii medycyny $\mathrm{w}$ miejsce zakładu powstał Zakład Przysposobienia Lekarskiego z tą samą obsadą.

W odniesieniu do łódzkiej historii farmacji badanego okresu odbywały się jedynie seminaria dla doktorantów przy ul. Lindleya 3, w wyasygnowanym do tego typu zajęć pokoju z podręczną biblioteczką, zawierającą ponoć „wartościowe egzemplarze”. Co oznaczać miało to określenie i do jakich ewentualnie dzieł się odwoływano, tego niestety nie podano w sprawozdaniu. Prowadzenie seminariów powierzono

\footnotetext{
${ }^{19}$ AAN, MZ, sygn. 21/1, k. 5 .

${ }^{20}$ Ibidem.

${ }^{21}$ Ibidem, k. 6.
} 
wówczas Robertowi Rembielińskiemu (1894-1975), zatrudnionemu na etacie zastępcy profesora historii farmacji. Skład osobowy zespołu dopełniać miał asystent Witold Piotrowski.

Nie sposób pominąć informacji na temat trzech kolejnych zakładów historii medycyny funkcjonujących w ramach poznańskiej, warszawskiej i wrocławskiej akademii lekarskich. Status materialny każdego z nich był jednak bardzo zróżnicowany, co w dużym stopniu było konsekwencją jego położenia geograficznego podczas wojny i okupacji. Najbardziej ucierpiał warszawski Zakład Historii Medycyny, całkowicie zniszczony podczas powstania. Po wojnie warunki lokalowe Uniwersytetu były na tyle tragiczne, że istniejącemu zakładowi nie przydzielono żadnego pomieszczenia, a ocalałe z pożogi wyposażenie umieszczono w Zakładzie Medycyny Sądowej przy ul. Oczki 5. Księgozbiór owego zakładu liczyć miał wówczas zaledwie 679 woluminów i, jak podkreślano $\mathrm{w}$ sprawozdaniu, nie stanowił $\mathrm{w}$ żadnym stopniu warsztatu pracy badacza historii medycyny. Brak było nie tylko encyklopedii, ale także podstawowych podręczników do historii medycyny. Biblioteką akademicką zarządzał prof. Wiktor Grzywo-Dąbrowski, który, jak zaznaczono w sprawozdaniu, czynić miał ogromne trudności w przypadku potrzeby skorzystania $\mathrm{z}$ księgozbioru. $\mathrm{Z}$ ośrodkiem warszawskim związany był doc. Górnicki, zatrudniony na etacie zastępcy profesora. Inni, luźno związani z placówką, to doc. Stanisław Konopka, dr Adam Smoluchowski, dr Zbigniew Woźniewski ${ }^{22}$.

Najkorzystniejsza pod względem materialnym była sytuacja poznańskiego i wrocławskiego ośrodków akademickich historii medycyny.

W Poznaniu Zakład Historii Medycyny zlokalizowany przy ul. Święcickiego 4 miał do dyspozycji jedną salę oraz aż cztery pokoje, co w porównaniu do wcześniej wymienionych placówek stanowiło dość istotną różnicę. Także zgromadzony księgozbiór liczyć miał wówczas ponad 3500 tomów. W ocenie autora podręczna biblioteczka była dobrze skompletowana. Podkreślano również możliwość utworzenia Muzeum Medycyny. Zespół pracowników tworzyli: na stanowisku kierownika - dr Ludmiła Krakowiecka-Wrzosek oraz asystent, lek. Roman Kaczorowski. W Zakładzie mieściła się również redakcja czasopisma „Archiwum Historii i Filozofii Medycyny”"23, prowadzona od samego początku, tj. od 1924 r., przez prof. Adama Wrzoska.

${ }^{22}$ Ibidem, k. 8.

${ }^{23}$ S. Konopka, Profesor dr Adam Wrzosek, redaktor i wydawca Archiwum Historii i Filozofii Medycyny w latach 1924-1949, „Archiwum Historii Medycyny” 1975, t. 38, z. 1, s. 3-10. 
Skład redakcji tworzyli wówczas m.in.: dr Edward Howorka, dr Maria Mastyńska oraz prof. med. Michała Ćwirko-Godycki. W Zakładzie mieściła się również Biblioteka Akademii Lekarskiej. Dział historii farmacji, a raczej wykłady zlecone $\mathrm{z}$ historii farmacji powierzono wówczas dr. Witoldowi Głowackiemu. Egzaminowanie doktorantów zaś doc. Konopce z Warszawy. Księgozbiór z historii farmacji zlokalizowany w Zakładzie Chemii Farmaceutycznej przy ul. Grunwaldzkiej nie przedstawiał dużej wartości ${ }^{24}$, o czym pisano w sprawozdaniu.

Najlepiej wyposażonym zakładem historii medycyny był wrocławski ośrodek zlokalizowany przy ul. Chałubińskiego 5. Ten z kolei zajmował dwa pokoje, a na wyposażeniu posiadał kilka szaf, stołów i biurko. Asortyment raczej skromny, jak podkreślano w sprawozdaniu, ale w gruncie rzeczy nie pokoje stanowiły o jego wartości. Księgozbiór, bo o nim mowa, odziedziczony po Zakładzie Historii Medycyny przedwojennego niemieckiego Uniwersytetu, liczyć miał w 1950 r. ok. 30 tys. tomów oraz dodatkowo tysiąc woluminów, które stanowić miały bibliotekę podręczną. Funkcję kierownika od 1945 r. aż do przejścia na emeryturę sprawował wspomniany już prof. Witołd Ziembicki. Dodatkowo na etacie adiunkta zatrudniono dr. Zdzisława Wiktora, a młodszymi asystentami było dwoje studentów - Izabela Kanionka i Janusz Kwaśnik. Z chwilą przejścia na emeryturę prof. Ziembickiego zakład został zlikwidowany ${ }^{25}$. Historią farmacji w badanym okresie nikt się nie zajmował.

Jak wynika z powyższego, sytuacja materialna zakładów historii medycyny nie przedstawiała się najlepiej. Należy jednak zauważyć, że w sprawozdaniu nie tyle chodziło o zaprezentowanie dokładnego wyposażenia jednostek naukowych, bo nie o liczbę stołów i krzeseł tak naprawdę chodziło, ile o przedstawienie możliwości rozwinięcia w przyszłości działalności naukowej. Istotna była w tym miejscu obecność i jakość zastanych księgozbiorów. Liczba woluminów czy tomów, nie wskazując na ich tytuły, niewiele jednak wnosiła do sprawozdania, choć dla ówczesnych władz zadowalająca mogła być ich dość lakoniczna ocena wystawiona przez autora, typu: „nie przedstawia wartości” czy „dobrze skompletowana”. Na temat jakości księgozbiorów zakładów wrocławskiego i poznańskiego można sądzić, że mimo wszystko zachowały się w nich wartościowe egzemplarze.

\footnotetext{
${ }^{24}$ AAN, MZ, sygn. 21/1, k. 7.

${ }^{25}$ Ibidem, k. 9.
} 


\section{Środowisko historyków medycyny w początkach lat. 50. XX w.}

Jak już wspomniano, dla ówczesnych władz państwowych najistotniejszą sprawą było rozpoznanie środowiska historyków medycyny i określenie ich przydatności i możliwości współpracy poszczególnych pracowników z komunistami.

Wspomniane już rozporządzenie z 1948 r. o zawieszeniu wykładów zapowiadało wprowadzenie zmian dostosowanych do obowiązującej ideologii marksistowsko-leninowskiej. Przedwrześniowym historykom zarzucano bowiem zbytni kosmopolityzm, trwały związek z zachodnią nauką i rzekomo statystyczne podejście do niej, które miało kolidować z oczekiwaniami materializmu dialektycznego, domagającego się od historii przede wszystkim podkreślenia jej dynamicznego rozwoju i społecznej roli ${ }^{26}$. Próbami opracowania nowego sposobu „uprawiania” historii medycyny zajęła się parę lat później specjalna Komisja Historii Nauk Medycznych, działająca w latach 1952-1956 przy Radzie Naukowej Ministerstwa Zdrowia. Na temat przebiegu spotkań i ewentualnych rezultatów pisano już wcześniej ${ }^{27}$.

Powróćmy jednak do zagadnień związanych z samym środowiskiem akademickim historyków medycyny. Jak wynika z powyższej prezentacji zakładów, skład osobowy poszczególnych placówek był mocno zawężony pod względem liczebnym. Wynikało to, jak można sądzić, nie tylko z braku akademickich etatów czy też dość wówczas nielicznego środowiska, ale przede wszystkim z powodu zachodzących zmian społeczno-politycznych w kraju. W nowo utworzonych akademiach lekarskich w Katowicach, Szczecinie i Białymstoku nie wyrażono zgody na powołanie zakładów historii medycyny.

Liczebność zastanych już zespołów była mocno zróżnicowana. W Krakowie w badanym okresie oprócz dr. Zdzisława Kukulskiego na etacie asystenta zatrudniono Tadeusza Dudkę. Dodatkowo z zakładem związani byli: Bronisław Wieczorkiewicz, a także doc. Jan Lachs, realizujący wykłady zlecone $\mathrm{z}$ historii farmacji.

Odmiennie przedstawiała się sytuacja w Warszawie, gdzie jedyną zatrudnioną w zakładzie osobą był jego kierownik - ówczesny doc. Bolesław Górnicki, a osobami luźno związanymi z placówką: doc. Stanisław Konopka, dr Adam Smoluchowski oraz dr Zbigniew Woźniewski.

\footnotetext{
${ }^{26}$ M. Paciorek, op. cit., s. 142.

${ }^{27}$ Ibidem.
} 
O historykach medycyny i zakładach naukowych pierwszej połowy lat 50 . XX w....

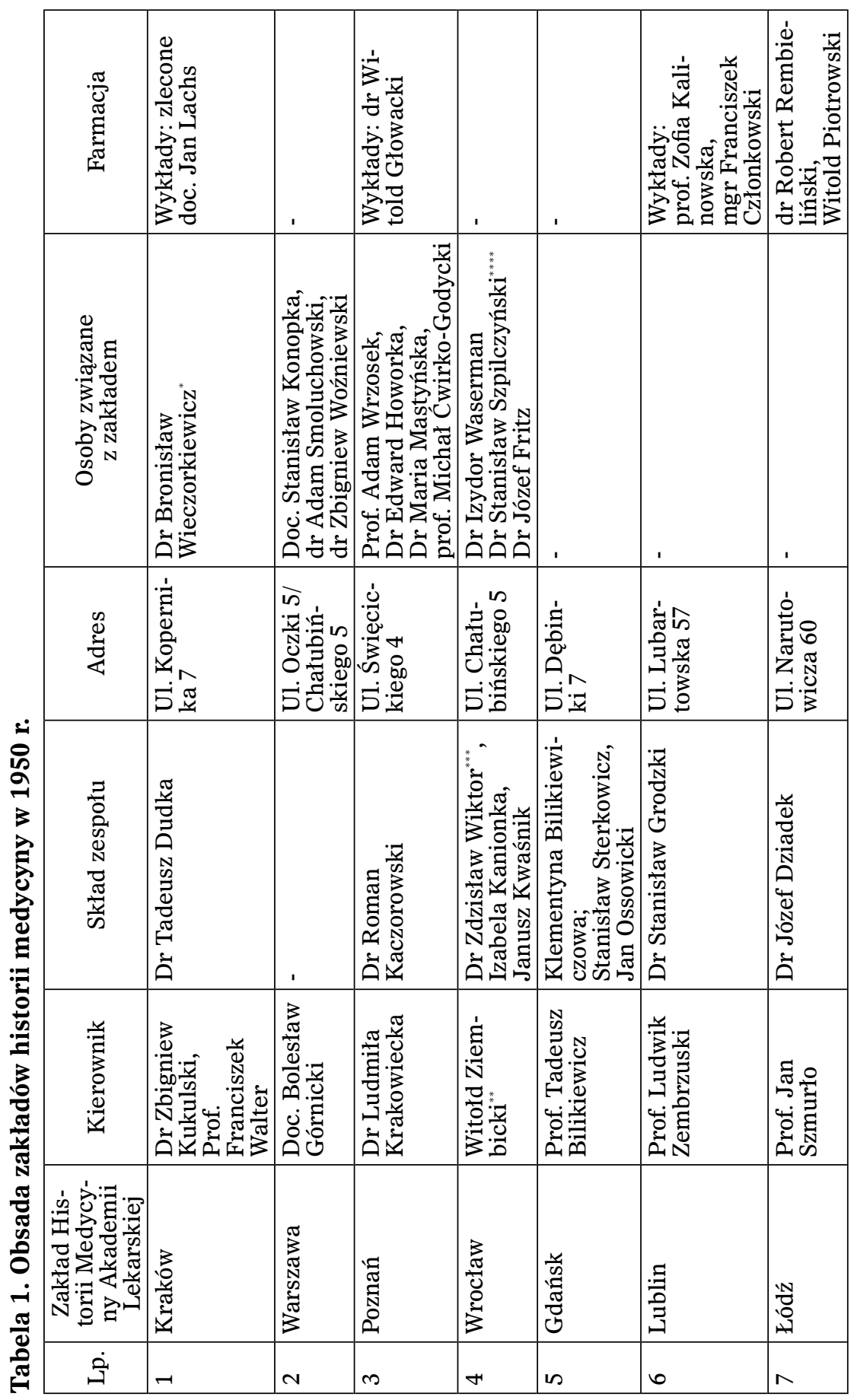

MEDYCYNA NOWOŻYTNA - Tom 27 - Zeszyt 2 (2021 r.) 
Młody lekarz związany z Zakładem, podopieczny dr. Kukulskiego, doktoryzował się 27 października 1951 r. Bronisław Wieczorkiewicz, Moje pótwiecze, [w:] E. Drobnik, J. Wunderlich (red.), Pamiętniki lekarzy, Warszawa 2004, s. 278.

** Kierownik od $1946 \mathrm{r}$.

*** Adiunkt w Zakładzie Historii Medycyny prowadzonej przez prof. Ziembickiego. Po likwidacji Zakładu w 1949 r. w latach 1950-1958 pełnił funkcje dyrektora biblioteki lekarskiej Akademii Medycznej we Wrocławiu, jednocześnie specjalizował się w nefrologii. J.B. Kos, Pochwycone w sieć pamięci, [w:] B.J. Kos (red.), Ocalić od zapomnienia: pamiętniki, wspomnienia i szkice biograficzne dolnośląskich lekarzy, Wrocław 2015, s. 259.

${ }^{* * * *}$ Stanisław Szpilczyński, związany z Wrocławiem od 1950 r., współpracownik Komisji Historii Medycyny i Nauk Przyrodniczych PAN. Od 1952 r. kierownik Zespołu Nauk Medycznych PAN we Wrocławiu. Ibidem, s. 259.

W Poznaniu, po odejściu prof. Adama Wrzoska na emeryturę, kierownictwo placówki objęła jego córka dr Ludmiła Krakowiecka. Drugą osobą był Roman Kaczorowski. Przy zakładzie funkcjonowało również nieprzerwanie od 1924 r. wydawnictwo Archiwum Historii Medycyny pod redakcją jego założyciela prof. Wrzoska. W skład zespołu redakcyjnego pisma wchodzili dodatkowo: dr Edward Howorka, Maria Mastyńska oraz prof. Michał Ćwirko-Godycki. Należy również dodać, że także historia farmacji, choć nie istniała jako samodzielny zakład, także miała swojego przedstawiciela. Był nim Witold Głowacki.

Z kolei we Wrocławiu w roku 1950 funkcję kierownika sprawował jeszcze (kilka miesięcy później zmarł) prof. Witołd Ziembicki. Na stanowisku adiunkta zatrudniony był dr Zdzisław Wiktor, a młodszych asystentów studenci Izabela Kanionka oraz Janusz Kwaśnik. Wśród osób związanych z zakładem pojawiało się nazwisko neurologa dr. Izydora Wassermana, dr. Stanisława Szpilczyńskiego oraz Józefa Fritza.

Przedstawicielem gdańskiego zakładu historii medycyny na początku lat 50. był prof. Tadeusz Bilikiewicz z asystentami: Klementyną Bilikiewiczową, Stanisławem Sterkowiczem oraz Janem Ossowickim.

W Lublinie zaś zakład historii medycyny powierzono prof. Ludwikowi Zembrzuskiemu, któremu do pomocy oddelegowano Stanisława Grodzkiego. Wykłady zlecone z historii farmacji powierzono wówczas prof. Zofii Kalinowskiej oraz Franciszkowi Członkowskiemu.

Z kolei w Łodzi zakład tworzyli prof. Jan Szmurło z asystentem dr. Józefem Dziadkiem. Wykładami z historii farmacji dla doktorantów zajął się wówczas dr Robert Rembieliński oraz Witold Piotrowski. 
Środowisko akademickich historyków medycyny i farmacji było również zróżnicowane pod względem wieku, jak i wiodącej profesji. Do najstarszych należał prof. Jan Szmurło - otolaryngolog, który w badanym okresie miał 83 lata. Niewiele młodszy był zasłużony dla polskiej historii medycyny prof. Jan Lachs - 81 lat; prof. Ludwik Zembrzuski - 79 lat; dalej: prof. Witołd Ziembicki - 76 lat; Adam Wrzosek - 75 lat; Robert Rembieliński - późniejszy profesor historii farmacji - 56 lat oraz doc. Stanisław Konopka - 54 lata. Młodsze pokolenie, niespełna pięćdziesięcio- i czterdziestolatków, tworzyli m.in.: prof. Tadeusz Bilikiewicz, Klementyna Bilikiewiczowa, Michał Ćwirko-Godycki, Bolesław Górnicki, Witold Głowacki, Ludmiła Krakowiecka, Józef Dziadek, Zdzisław Wiktor, Stanisław Szpilczyński, Zbigniew Woźniewski oraz Adam Smoluchowski. Do najmłodszych należeli m.in. Izabela Kanionka oraz Adam Kwaśnik, Stanisław Sterkowicz i Witold Piotrowski - wówczas studenci medycyny i farmacji. Dla niektórych etat $\mathrm{w}$ zakładzie historii medycyny stanowił epizod w karierze zawodowej. Dla innych był początkiem pogłębiania zainteresowań w dziedzinie historii medycyny. Jak z powyższego wynika, zdecydowana większość środowiska medycznego parającego się historią medycyny była lekarzami różnych specjalności. Zaledwie dwie osoby - Ludmiła Krakowiecka i Klementyna Bilikiewiczowa - reprezentowały inne wykształcenie wyższe. Pierwsza z nich z zawodu była prawnikiem i filozofem, druga zaś historykiem (jak pisał po latach jej mąż prof. Tadeusz Bilikiewicz ${ }^{28}$ ). Ich związek z historią medycyny w dużym stopniu uwarunkowany był wcześniejszymi koneksjami rodzinnymi. O ile kariera naukowa Klementyny Bilikiewiczowej była raczej nastawiona na pomoc mężowi ${ }^{29}$, o tyle Ludmiła Krakowiecka przejęła po ojcu dalszą działalność zakładu, habilitowana w 1950 r., formalnej profesury jednak się nie doczekała.

Interesująca wydaje się też informacja na temat przynależności poszczególnych osób do organizacji partyjnych. $Z$ danych pochodzących z cytowanych już dokumentów archiwalnych wynika, że zdeklarowanym członkiem ówcześnie rządzącej partii w środowisku akademickich historyków medycyny był Adam Smoluchowski, Izydor Wasermann oraz Zbigniew Kukulski. Do ZMP należeli studenci będący na etatach uczelnianych. Ta przynależność, jak wiadomo, była $\mathrm{w}$ badanym okresie bardzo pomocna w uzyskaniu etatu na uczelni.

${ }^{28}$ T. Bilikiewicz, Wspomnienia autobiograficzne, „Kwartalnik Historii Nauki i Techniki" 1978, nr 1, s. 3-52.

${ }^{29}$ Tadeusz Bilikiewicz pisał: „całe życie pomagała mi w moich pracach”. Ibidem. 


\section{Środowisko historyków medycyny w świetle sprawozdania z objazdu zakładów naukowych}

Sprawozdanie z 1950 r. Adama Smoluchowskiego z objazdu po zakładach historii medycyny stanowi niewątpliwie bardzo interesujący, ale też mocno kontrowersyjny dokument charakteryzujący m.in. ówczesne środowisko historyków medycyny. Obawy wzbudza m.in. brak autoryzacji wypowiedzi poszczególnych rozmówców. Ponadto już samo zaangażowanie autora i wierność nowej ideologii stawia jego ocenę środowiska pod znakiem zapytania co do jej rzetelności. Biorąc pod uwagę realia ówczesnych lat i sytuację społeczno-polityczną zleceniodawcy cytowanego raportu zamierzali uzyskać odpowiedź w kwestii poglądów i możliwości ideologizacji środowiska naukowego historyków medycyny.

Należy podkreślić, że zgodnie z oczekiwaniami ówczesnych władz pytania skierowane do rozmówców dotyczyć miały m.in. pochodzenia społecznego, przynależności do partii komunistycznej, dalej: wykształcenia, przebiegu pracy zawodowej, dotychczasowych dokonań naukowych. W dalszej części wypowiadano się na temat bieżących zainteresowań i planów na przyszłość. Należy podkreślić, że właśnie te informacje były traktowane jako niezmiernie istotne. Świadczyły o tym dokonane na dokumentach podkreślenia czerwonym ołówkiem.

Równie istotna, a zarazem wzbudzająca najwięcej kontrowersji jest ostatnia część ,ankiety”, w której rozmówca wyraża opinie o poszczególnych osobach, powołując się na wcześniej zasłyszane doniesienia. Oceny te często były bardzo krytyczne, niepozbawione dosadnych epitetów, co już na tym etapie wzbudza pewne podejrzenia w kwestii ich wypowiedzenia. Krytyka dotyczyć miała nie tylko dokonań naukowych, ale także poglądów i przekonań, zazwyczaj tych odmiennych od ówcześnie przyjętych i uważanych za „słuszne”. Podsumowaniem była opinia autora wystawiona każdemu pracownikowi zakładu; zazwyczaj zwięzła, jednozdaniowa, zawierająca tym samym odpowiedź na temat przyszłych oczekiwań.

Czy wobec takiego stanu rzeczy omawiane sprawozdanie stanowi jakąś wartość? Historyczną zapewne tak, bo jest kolejnym przykładem sposobu sprawowania władzy ówczesnych rządzonych, polegającym m.in. na promowaniu własnych członków partii bądź ludzi podobnie jak oni myślących. Z kolei oponentom poświęcano więcej uwagi, szukając, jeśli nie w ich dorobku naukowym, to w ocenie ich środowiska, potwierdzenia opinii władzy. 
Przytoczenie pewnych fragmentów dość obszernego dokumentu ma na celu odzwierciedlenie m.in. ówczesnego klimatu tamtej epoki w odniesieniu do pewnej grupy społeczności naukowej.

Stanisław Konopka, uczeń prof. Wrzoska, przed wojną kierownik Biblioteki Lekarskiej CWSan., podczas okupacji lekarz szpitala ujazdowskiego, więzień obozów koncentracyjnych w Majdanku, GrosRosen i Litomierzycach, po wojnie zaś dyrektor Lekarskiego Instytutu Naukowo-Wydawniczego i Głównej Biblioteki Lekarskiej oraz egzaminator doktorantów $\mathrm{z}$ historii medycyny.

W opinii środowiska przez jednych uważany był „(...) za jednego z najgenialniejszych pedagogów doby obecnej” (Woźniewski). Inni mieli w nim widzieć tylko bibliografa (Szmurło, Wrzosek, Ziembicki). Dla Górnickiego - jak pisano w sprawozdaniu - „ujęcie przez Konopkę historii medycyny jest obrazą dla tego przedmiotu" ${ }^{30}$. Sam Konopka miał ponoć uważać za historyków medycyny tylko tych, „którzy siedzieli w bibliotece praktycznie rzecz biorąc jedynie siebie"31 - dodawano.

Jan Lachs - najstarszy spośród historyków, krakowski ginekolog, docent historii medycyny. $\mathrm{W}$ okresie przedwojennym zatrudniony $\mathrm{w}$ ubezpieczalniach społecznych w Krakowie, w czasie wojny lekarz ginekolog w jednym ze szpitali gminy żydowskiej, a od 1947 r. wykładowca zleconych wykładów z historii farmacji Wydziału Farmaceutycznego UJ. W listopadzie 1948 r., jak donoszono w sprawozdaniu, wspomniany Wydział Farmaceutyczny zwrócił się do ówczesnego Ministerstwa Oświaty z propozycją mianowania Lachsa profesorem tytularnym. Pismo zostało wystosowane w lutym 1949 r. Odpowiedź uzyskano w styczniu następnego roku, z wyjaśnieniem, że z powodu braku „załączników” sprawę tę zawieszono. Warto zwrócić uwagę na daty, a właściwie na rozwlekłość procesu załatwiania danej sprawy, co sugerowałoby tzw. granie na zwłokę. Jak można sądzić, uwzględniając ówczesną niewyjaśnioną sytuację historii medycyny, tego typu postępowanie stanowi kolejny dowód stosunku ówczesnych władz do przedstawicieli środowiska historyków medycyny.

Wracając do oceny Lachsa, w opinii sprawozdawcy za istotne podkreślenia uważano zacytowanie jego jednej z opinii, która mogła wydawać się kontrowersyjna w badanym okresie. W sprawozdaniu pisano wówczas: „sądzi [Lachs - przyp. aut.], że studenci farmacji powinni słuchać wykładów z filozofii ścisłej na wydziałach humanistycznych. Uważa, że na to ażeby w Polsce znaleźli się historycy medycyny na-

\footnotetext{
${ }^{30}$ AAN, MZ, sygn. 21/1, k. 23.

${ }^{31}$ Ibidem.
} 
leży stworzyć narybkowi warunki materialne i pracy. Przedmiotowi temu bowiem należy poświęcić się całkowicie, nie można go uprawiać jako zajęcie boczne"32.

W opinii niektórych swoich kolegów (Rembieliński, Kukulski) postrzegany był jedynie za „przyczynkowca”. Rembieliński miał ponoć twierdzić, że Lachs nie nadał się na wykładowcę, ponieważ nie był $\mathrm{z}$ zawodu farmaceutą. Innym zarzutem parokrotnie powtarzanym był jego zaawansowany wiek. W sprawozdaniu bez ogródek pisano wówczas, że po prostu jest „bardzo stary”33.

Z kolei wspomniany wyżej dr farmacji Robert Rembieliński ${ }^{34}$ w badanym okresie zatrudniony był na stanowisku zastępcy profesora propedeutyki historii farmacji. Z racji zawieszenia wykładów również i jego habilitacja nie doszła do skutku i - jak określano w sprawozdaniu - „stanęła w martwym punkcie” ${ }^{35}$. Mimo to Rembieliński deklarował swą dalszą aktywność naukową.

Na temat innych kolegów w opinii cytowanego dokumentu Rembieliński dobrze wyrażał się m.in. o W. Głowackim jako o „młodym, poważnym i bardzo pracowitym człowieku" ${ }^{36}$. Z kolei o Bilikiewiczu miał twierdzić, że „nie odczuwa ducha współczesności, myśląc starymi idealistycznymi kategoriami" ${ }^{37}$.

O nim samym wyrażano się $\mathrm{w}$ takim tonie, że „(..) ma najlepszą wolę przystosowania się do obecnej rzeczywistości nie mając jednak zdecydowanego światopoglądu marksistowskiego, błąka się"38. Sam autor sprawozdania, pisząc o Rembielińskim, podkreślił jego ambicję oraz fakt, że podczas wykładów opiera się na literaturze radzieckiej.

Warty uwagi i podkreślenia wydaje się osąd nad dr. Stanisławem Szpilczyńskim z Wrocławia. Dla przypomnienia należy podkreślić, że neurolog ten w roku $1945 \mathrm{r}$. był jednym z członków grupy naukowej, która przybyła do Wrocławia w celu zabezpieczenia majątku uniwersyteckiego przed zniszczeniem. Był również m.in. twórcą tamtejszej Kliniki Neurologiczno-Psychiatrycznej.

Opinie na temat jego osoby i pracy naukowej - w ocenie autora sprawozdania - nie były zbyt pochlebne. Postrzegano go jako „wiecz-

${ }^{32}$ AAN, MZ, sygn. 21/1, k. 28.

${ }^{33}$ Ibidem.

${ }^{34}$ H. Pankiewicz, Profesor dr farmacji Robert Rembieliński 1894-1975, „Archiwum Historii Medycyny” 1976, t. 39, z. 1, s. 1-5.

${ }^{35}$ AAN, MZ, sygn. 21/1, k. 31.

${ }^{36}$ Ibidem, k. 32.

${ }^{37}$ Ibidem.

${ }^{38}$ Ibidem. 
nego malkontenta, dyletanta, chwytającego się wszystkiego"39. Zarzucano mu brak krytycyzmu. Pisano, że jest „lekkomyślny i nieobliczalny"40. Pojawiały się również i inne epitety, jak: szałaput, psychopata, półgłówek czy oszust. Jedynie Adam Wrzosek i rektor wrocławskiej uczelni Kulczyński o Szpilczyńskim i jego dorobku naukowym wyrażali się pozytywnie.

W rozmowie z autorem sprawozdania Szpilczyński miał rzekomo wypowiedzieć kilka uwag, które - zaprotokołowane w sposób fragmentaryczny - przedstawiały go w niekorzystnym świetle. Czy było to zamierzone? Trudno ocenić z perspektywy czasu, jednak biorąc pod uwagę ówczesną komunistyczną rzeczywistość, było to bardzo możliwe.

Smoluchowski pisał o nim: „nie rozumie jak można łączyć medycynę z «polityką». Uważa medycynę za naukę zupełnie oderwaną. Siebie uważa za szperacza, twierdzi, że z historii medycyny należy wydobywać na światło dzienne różne ciekawostki. Charakter jego prac to klasyczne anegdociarstwo, a w najlepszym przypadku przyczynkarstwo. Zamierza poświęcić się neurologii i robić tylko karierę jako neurolog. Zgadza się na uboczne zajmowanie historią medycyny"41.

Jednym z najstarszych, jak już wspomniano, historyków medycyny był otolaryngolog prof. Jan Szmurło. Pomimo zaawansowanego wieku zatrudniony był na stanowisku profesora historii medycyny Uniwersytetu Łódzkiego, później zaś profesora kontraktowego przysposobienia lekarskiego łódzkiej Akademii Lekarskiej.

W ocenie rektora tamtejszej uczelni prof. Emila Palucha Szmurło postrzegany był za uczonego, który idzie z prądem czasu i - co ciekawe - „ma niesłychanie żywy umysł” mimo swojego wieku. Znaleźli się jednak i oponenci, którzy zarzucali Szmurle, że nie jest historykiem, a jedynie anegdotykiem ${ }^{42}$. Z kolei autor sprawozdania pisał o nim następująco: „historię pojmuje jako zbiór oderwanych biografii, nie widzi w niej żadnych problemów, w ogóle nie rozumie dlaczego zawieszono wykłady z historii medycyny"43. W dalszej części pisał o Szmurle: „uważa, że etyka Biegańskiego, etyka lekarza mieszczańskiego z końca XIX w., jest sprawą zasadniczą, którą trzeba przede wszystkim głosić na wykładach historii medycyny. Prof. Szmurło był postępowcem XIX wieku obecnie jego hasła wyglądają dziwnie" 44 .

\footnotetext{
${ }^{39}$ Ibidem, k. 35 .

40 Ibidem, k. 36.

41 Ibidem.

42 Ibidem, k. 37.

43 Ibidem.

44 Ibidem.
} 
Na uwagę zasługuje też prezentacja prof. Adama Wrzoska, emerytowanego profesora poznańskiego wydziału lekarskiego, którego postać $\mathrm{z}$ różnych względów nie mogła być pominięta $\mathrm{w}$ sprawozdaniu. Należał bowiem do grupy tzw. starej profesury, niewygodnej dla komunistów, a której zamierzano się jak najszybciej pozbyć. W przypadku prof. Wrzoska rażący był, ich zdaniem, m.in. jego katolicyzm oraz przedwojenna aktywność państwowa ${ }^{45}$. W roku 1947 wysłany został na przymusową emeryturę. Wszelkie próby odwołania się od tej decyzji, która nota bene zapadła już wcześniej na stanowiskach ministerialnych, spełzły na niczym. Dopiero dzięki dobrej woli przyjaciela Jana Czekanowskiego prof. Wrzosek został ponownie zatrudniony $\mathrm{w}$ Zakładzie Antropologii na stanowisku asystenta, a później docenta ${ }^{46} . \mathrm{Na}$ stanowisko profesora Zakładu Historii Medycyny powrócił dopiero w $1957 \mathrm{r}$.

W cytowanym sprawozdaniu opinie o Wrzosku zdawały potwierdzać istniejącą niechęć ludzi władzy do jego osoby. Ówczesny dziekan WL prof. Tadeusz Kurkiewicz podkreślał jego „wojujący klerykalizm destrukcyjnie działający na cały Wydział Lekarski i studentów tak swymi poglądami jak również swym postępowaniem"47. Zarzucano Wrzoskowi m.in. promowanie prac doktorskich o niskim poziomie naukowym. Twierdzono, że średni czas pisania pracy u prof. Wrzoska trwał ok. 3 miesiące, po czym kandydat był promowany. Stąd - według sprawozdania - ponad $80 \%$ doktorantów było prof. Wrzoska ${ }^{48}$. W odniesieniu do ostatniego twierdzenia warto podkreślić jego niezwykłą pod tym względem pracowitość. W rzeczywistości prof. Wrzosek wypromował całą rzeszę doktorantów i habilitantów, m.in. 48 z zakresu historii medycyny, $8 \mathrm{z}$ antropologii ${ }^{49}$.

W opinii środowiska historyków medycyny zdania na temat Wrzoska, jak i jego działalności naukowej miały być podzielone. Zarzucano (Walter, Górnicki, Ziemnicki) jego pracom uprawianie bardziej dziennikarstwa aniżeli naukowości. Ponadto twierdzono, że „Archiwum Historii Medycyny” wydawane pod jego redakcją prezentuje niski

45 Pełnił funkcję dyrektora Departamentu Sekcji Nauki i Szkół Akademickich w MWRiOP. R.W. Gryglewski, Historia medycyny jako przedmiot badań i nauczania w krakowskim środowisku uniwersyteckim w latach 1809-1914, Kraków 2015, s. 205. Zob. też: S. Jankowiak, S. Schramm (red.), Dzieje Uniwersytetu w Poznaniu w latach 1945-2019, Poznań 2019, s. 17-18.

46 S. Konstańczak, Wkład Adama Wrzoska $w$ odbudowe szkolnictwa medycznego w Poznaniu, „Akta Medicorum Polonorum” 2020, z. 1, s. 23.

${ }^{47}$ AAN, MZ, sygn. 21/1, k. 42.

${ }^{48}$ Ibidem.

${ }^{49}$ S. Konstańczak, op. cit., s. 31. 
poziom publikacji i - jak określano - „podejście średniowieczne”50. Z kolei Szmurło i Woźniewski na temat Wrzoska wypowiadali się pozytywnie. Mówiono o nim jako światłym i trzeźwym umyśle. A dla Woźniewskiego Wrzosek miał być „chodząca encyklopedią o kolosalnej płodności naukowej"s1.

Z kolei Wrzosek dobrze wypowiadał się o Peterze. Konopka był dla niego jedynie bibliografem zaś Górnickiego postrzegał jako człowieka chaotycznego.

Sam autor sprawozdania o cytowanym Wrzosku wystawił niezbyt pochlebną opinię. Pisał wówczas „osobiście stwierdziłem u Wrzoska objawy sklerotyczne, bezkrytyczność i tkwienie w przeszłości ze wszystkimi złymi narowami świata profesorskiego". Jeśli wziąć pod uwagę stosunek Smoluchowskiego do ówczesnej rzeczywistości, trudno było spodziewać się odmiennej opinii.

Kolejnym historykiem związanym $\mathrm{z}$ warszawskim zakładem historii medycyny był cytowany już parokrotnie doc. Bolesław Górnicki, uczeń prof. Wrzoska, choć - jak sugerowano w sprawozdaniu - sam zainteresowany ponoć „nie uważał się za człowieka Wrzoska”52. Habilitował się w 1947 r. z historii medycyny. Po wojnie od samego początku piastował stanowisko zastępcy profesora Zakładu Historii Medycyny UW. Funkcję tę pełnił do 1948/1949. Jednocześnie zatrudniony był jako pediatra w Klinice Chorób Dziecięcych UW.

Na temat rzekomych wypowiedzi Górnickiego o starszych kolegach (Wrzosek, Konopka) pisano już wcześniej. Z kolei o Zbigniewie Kukulskim twierdził, że „ma zrozumienie dla obecnej rzeczywistości”, Bilikiewicz zaś - związany z gdańskim zakładem historii medycyny - według Górnickiego był „tylko rozsądnym człowiekiem”53, co miało oznaczać, że nie dostrzegał w nim żadnego potencjału historyka.

Na temat Górnickiego wspomniany Kukulski wypowiadał się jako o tzw. przyczynkowcu i bibliografie, jednak o tyle wartościowszym od Konopki, „że zdaje sobie sprawę z prądów współczesnych i mającego najlepszą wolę nagięcia się do nich”. Choć, jak dalej dopowiadał, „nie jest prawdopodobnie postępowcem, nie interesuje go zupełnie problematyka i nigdy nie uchwyci granicy między medycyną zacofaną i postępową" ${ }^{54}$. Starsi historycy (Wrzosek, Ziembicki) mieli dostrzegać w nim człowieka chaotycznego.

\footnotetext{
50 AAN, MZ, sygn. 21/1, k. 42.

51 Ibidem.

52 Ibidem, k. 20.

53 Ibidem.

54 Ibidem.
} 
Sam Smoluchowski, podsumowując powyższe opinie, pisał, że według niego „Górnicki ma najlepszą chęć i wolę pracować w historii przy uwzględnieniu materializmu dialektycznego i historycznego. Sam jest dość oczytany w literaturze marksistowskiej" ${ }^{55}$. Zdanie to na tyle było istotne, że zostało podkreślone czerwonym ołówkiem. Kolejne zdania nie przypadły już tak do gustu adresatowi sprawozdania. Warto jednak zacytować ciąg dalszy opinii autora. Pisał on m.in.: „[Górnicki] uważa, że historykowi nie potrzebna jest przynależność partyjna, natomiast musi sobie przyswoić ujęcie dialektyczne historii i odpowiednie fragmenty filozofii materialistycznej. Uważa, że historia medycyny musi mieć cele praktyczne i cechy dydaktyczne".

Postać Witołda Ziembickiego również znalazła swoje miejsce w sprawozdaniu. Pokrótce wspomniano jego lwowską przeszłość. Warto jednak zaznaczyć, że historią medycyny zajął się tak naprawdę dopiero po przejściu na emeryturę w 1935 r. Rok później został mianowany profesorem tytularnym, gdzie kierował tamtejszym Zakładem Historii Medycyny. Po zakończeniu wojny przez krótki czas prowadził wykłady w Krakowie w zastępstwie prof. W. Szumowskiego, następnie współtworzył Zakład Historii Medycyny we Wrocławiu. Był też pierwszym dyrektorem Biblioteki wrocławskiego Wydziału Lekarskiego ${ }^{56}$.

Wracając do sprawozdania, w ocenie jego autora Ziembicki zaprezentowany został jako osoba apodyktyczna, nieznosząca sprzeciwu, bardzo krytyczna wobec innych kolegów, posługująca się przy tym dosadnymi epitetami, typu: schizol, dyletant, grafoman, epileptyk, oszust, półgłówek psychol ${ }^{57}$. Czy rzeczywiście tak było? Trudno obecnie dociec prawdy. Równie negatywnie miał być ustosunkowany do swojego pracownika dr. Zdzisława Wiktora. Z kolei dr I. Wassermana cenić miał za jego oczytanie. Ten zaś postrzegał rzekomo profesora jako człowieka bardzo przebiegłego i sprytnego ${ }^{58}$.

Profesor Tadeusz Bilikiewicz od 1946 r., czyli od samego początku, związany był z gdańskim zakładem historii medycyny. Pokrótce wspomniano jego przedwojenną działalność naukową. Smoluchowski uważał też za istotne poruszenie kwestii odroczenia habilitacji Bilikiewicza z psychiatrii. Praca habilitacyjna zatytułowana Psychologia

55 Ibidem.

56 Z. Domosławski, Ziembicki Witołd (1874-1950), [w:] Z. Podgórska-Klawe (red.), Słownik biograficzny polskich nauk medycznych XIX i XX w., t. 1, z. 2, Warszawa 1994, s. 1949-1951.

57 AAN, MZ, sygn. 21/1, k. 43.

58 Ibidem. 
marzenia sennego w 1949 r. nie została przyjęta przez Radę Główną ${ }^{59}$. Jak sugerować miał Smoluchowski, Bilikiewicz twierdził, iż przyczyną jej odrzucenia były nieporozumienia interpersonalne. W dokumencie czytamy: „Według zdania Bilikiewicza skrytykował ją Handelsman w odwet za ujemną krytykę Mazurkiewicza dokonaną przez Bilikiewicza”. O swojej pracy prof. Bilikiewicz miał też twierdzić, że „odrzucona praca habilitacyjna (...) nie jest idealistyczna, nie ma w niej dualizmów, oznacza się przyrodniczą metodyką, zresztą jest to książka pisana przed wojną" ${ }^{\circ}$. W 1950 r. Bilikiewicz nadal sprawował funkcję kierownika Kliniki Psychiatrycznej w Kocborowie oraz był profesorem w stanie spoczynku zakładu historii medycyny.

W opinii kolegów (Górnicki, Woźniewski, Kukulski) - zdaniem autora sprawozdania - Bilikiewicz postrzegany był przede wszystkim jako psychiatra i ta specjalność miała zdecydowanie dominować w jego dorobku naukowym. Niektórzy (prof. L. Fleck) mieli nawet sugerować Bilikiewiczowi, że „aby z powrotem stać się wartościowym dla historii, do której ma ogromne przygotowanie, musi bezwzględnie rzucić psychiatrię"61.

Z kolei w rozmowie ze Smoluchowskim wyrażał pogląd dość niebezpieczny w badanym okresie. Miał bowiem twierdzić, że wszystko jest względne, włącznie z materializmem. Ponadto wykazywał niezrozumienie dążenia do zmian w podejściu do nauki i „prawdę mówiąc nie orientuje się dobrze o co tu chodzi” 62 .

Zbigniew Kukulski ${ }^{63}$ należał do grupy młodszych kolegów w środowisku historyków medycyny, jednak bardzo wcześnie przejął kierownictwo krakowskiego zakładu historii medycyny po ustępującym prof. Szumowskim. Z zawodu dermatolog, dla ówczesnych władz istotna była jego przynależność do PPS, a następnie PZPR. W opinii kolegów pisano o nim, że miał „zrozumienie do otaczającej rzeczywi-

${ }^{59}$ Rada Główna ds. Nauki i Szkolnictwa Wyższego w 1949 r. odrzuciła pracę habilitacyjną Psychologia marzenia sennego T. Bilikiewicza z powodu elementów idealistycznych. Mimo to Rada Wydziału Lekarskiego AM w Gdańsku powołała go na stanowisko kierownika Katedry Psychiatrii. Sprawa habilitacji ciągnęła się jeszcze przez kolejne trzy lata. Ostatecznie w roku 1953 zyskał stopień doktora nauk medycznych, według systemu radzieckiego, odpowiadającego doktorowi habilitowanemu, a przywróconemu po październiku 1956 r. R. Kujawski, Tadeusz Bilikiewicz - psychoterapeuta w dwudziestoleciu międzywojennym cz. 2. Onejroanaliza, „Psychiatria i Psychoterapia” 2017, nr 4, s. 35. Zob. też: http://www.wiw.pl/wielcy/kwartalnik/BilikiewiczTadeusz_08.asp [dostęp: 5.12.2021].

${ }^{60}$ AAN, MZ, sygn. 21/1, k. 10.

61 Ibidem.

${ }^{62}$ AAN, MZ, sygn. 21/1, k. 12.

${ }^{63}$ M. Skulimowski, Doc. dr med. Zbigniew Skulimowski (1908-1971), „Archiwum Historii Medycyny" 1972, t. 35, z. 1/2, s. 185-188. 
stości”. Zatem dostrzegano w nim potencjał, zwłaszcza że w konkluzji dodawano informację, że Kukulski był dość otrzaskany w literaturze marksistowskiej ${ }^{64}$.

Zdecydowanie więcej uwagi $\mathrm{w}$ sprawozdaniu poświęcono cytowanemu już dr. Zdzisławowi Wiktorowi ${ }^{65}$, asystentowi, a następnie adiunktowi wrocławskiego zakładu historii medycyny. Spośród szeregu nic nie wnoszących informacji o omawianym pracowniku naukowym Smoluchowski zawarł jednak też takie, które wydają się kontrowersyjne. $Z$ jednej strony miał podkreślać jego odmienność poglądów, np. na zjawisko współzawodnictwa pracy w badanym okresie, z drugiej zaś informował o rzekomej przemianie zachodzącej w Wiktorze. Według autora sprawozdania Wiktor miał twierdzić, iż cały swój dotychczasowy dorobek naukowy uważa za błędny i że obecnie jest w fazie „głębokiego przemieniania się"66. Także fakt korzystania z podręcznika Szumowskiego podczas wykładów miał obecnie postrzegać jako coś niewłaściwego, jednak nakazanego przez prof. Ziembickiego. Owa rzekoma publiczna samokrytyka, charakterystyczna dla badanego okresu, stała jednak w sprzeczności z jego nieukrywanym katolicyzmem. W podsumowaniu Smoluchowski miał stwierdzić, że ta „pseudopostępowość” $\mathrm{w}$ wypowiedziach Wiktora miała być jednak pozorna i na pokaz.

W odniesieniu do pozostałych członków środowiska historyków medycyny uwagi Smoluchowskiego były zazwyczaj krótkie i lakoniczne, jednak podkreślające istotne dla ówczesnej władzy szczegóły. $\mathrm{Na}$ początku lat 50. przyznawanie się do katolicyzmu, jak było w przypadku Ludmiły Krakowieckiej, zazwyczaj odbierano niekorzystnie. Także deklaracje zerwania z historią medycyny zawierały jednoznaczny przekaz. Tak było w przypadku dr. Stanisława Grodzkiego, asystenta prof. Ludwika Zembrzuskiego z lubelskiej Akademii Medycznej, dalej: dr. Edwarda Howorka ${ }^{67}$ z Poznania czy psychiatry dr. Izydora Wasermanna $^{68}$. Ten ostatni miał jedynie godzić się na prowadzenie w przyszłości wykładów zleconych. O Witoldzie Głowackim - farmaceucie, opierając się na zasłyszanych opiniach, Smoluchowski miał wyrażać dobrą opinię, choć jak podkreślał - osobiście z nim nie rozmawiał i „trudno obecnie powiedzieć czy Głowacki rozumie potrzebę

${ }^{64}$ AAN, MZ, sygn. 21/1, k. 24-25.

${ }^{65}$ S. Konopka, Zdzisław Wiktor (1911-1970) historyk medycyny i profesor nefrologii Akademii Medycznej we Wrocławiu, „Archiwum Historii Medycyny” 1970, t. 33, z. 2, s. 239-246.

${ }^{66}$ AAN, MZ, sygn. 21/1, k. 40.

${ }^{67}$ Ibidem, k. 21.

${ }^{68}$ Ibidem, k. 38. 
dialektycznego rozpatrywania historii" ${ }^{69}$. Zbigniewa Woźniewskiego z kolei, warszawskiego chirurga, związanego ze Szpitalem Wolskim, postrzegać miał jako człowieka, któremu imponują starsi historycy medycyny i stara się do nich upodobnićc ${ }^{70}$. Jak można sądzić, opinia ta, w ocenie autora, nie była pochlebna dla ocenianego.

$\mathrm{W}$ podsumowaniu powyższych rozważań należy podkreślić, że wizytacja zakładów, jak i środowiska historyków medycyny lat 50. w opinii dr. Smoluchowskiego nie wypadła najkorzystniej. O ile kwestia samych zakładów ocalałych z pożogi wojennej nie budzi większych wątpliwości, o tyle zaprezentowany przez autora klimat współpracy wśród historyków medycyny wydawał się jednak niedopuszczalny. Przedstawiono bowiem wizję środowiska bardzo skonfliktowanego wewnętrznie, pełnego uprzedzeń, zatarć i niesnasek. Być może o to też chodziło autorowi, by stworzyć obraz niespójnej społeczności akademickich historyków medycyny, mocno przywiązanych do przedwojennego sposobu uprawiania historii, o dorobku mało wartościowym. Jak wynika z przedstawionych relacji, spośród ponad 30 nazwisk lekarzy i profesorów zaledwie garstka ich przedstawicieli miała spełniać wymogi stawiane przez ówczesnych rządzących. Ale i oni, jak np. Izydor Wasermann czy Bronisław Wieczorkiewicz, mieli deklarować jedynie uczestnictwo w wykładach zleconych. Większość środowiska historyków medycyny postrzegano jako funkcjonujące odrębnie jednostki, którym z reguły zarzucano w pracach przyczynkarstwo, kronikarstwo, dziennikarstwo. Także sposób uprawiania historii medycyny przez historyków postrzegano jako nieodpowiedni i niewłaściwy. Wrzoskowi zarzucano m.in. wypromowanie całej rzeszy doktorantów, których prace miały być pisane zbyt pospiesznie, stąd ich ogromna liczba. $\mathrm{Z}$ kolei etyka W. Biegańskiego propagowana podczas wykładów przez prof. Szmurłę stała w sprzeczności z ówcześnie obowiązującą ideologią marksistowską. Ostrej krytyce poddano również poziom prac publikowanych w „Archiwum Historii i Filozofii Medycyny” prof. Wrzoska. Pisano m.in.: „w dobie obecnej, gdy dążymy aby oprzeć historię medycyny na jak najbardziej naukowych, materialistycznych zasadach rola [czasopism] jest odmienną niż przedtym" "11. Czasopisma miały bowiem podlegać ogólnej ideologicznej polityce wydawniczej.

Przechodząc do wskazania nazwisk „godnych uwagi”, pewien potencjał $\mathrm{w}$ badanym okresie przypisywano m.in. B. Górnickiemu,

\footnotetext{
${ }^{69}$ Ibidem, k. 18 .

${ }^{70}$ Ibidem, k. 41.

${ }^{71}$ Ibidem, k. 46.
} 
Z. Kukulskiemu, a także sam Smoluchowski widział się na stanowiskach kierowniczych zakładów historii medycyny. Spośród historyków farmacji wymieniano nazwisko Głowackiego, Rembielińskiego. Do pracy zamierzano zachęcić też młodych, w tym studentów medycyny i farmacji. Widziano w swoich szeregach oprócz wspomnianych także Piotrowskiego, Sterkowicza, Dudkę, jednak należało ich odpowiednio ukształtować.

Jak zatem z powyższego wynika, sprawa zakładów historii medycyny, jak i jej obsady oraz przyszłości historii medycyny w nowej, powojennej rzeczywistości przedstawiała się dość poważnie. Należy zgodzić się z autorem sprawozdania, który w podsumowaniu stwierdzić miał, że „do zagadnienia historii medycyny w Polsce trzeba podchodzić bardzo poważnie"72.

\section{Bibliografia}

Archiwum Akt Nowych, Ministerstwo Zdrowia, sygn. 21/1. Sprawozdanie z objazdu naukowego po zakładach naukowych 1950.

AAN, MZ, sygn. 5/1.

Archiwum Uniwersytetu Jagiellońskiego, sygn. SIII-32, Sprawozdanie z działalności Zakładu Historii Medycyny rok 1945.

Archiwum Uniwersytetu Jagiellońskiego, sygn. SIII-33, Sprawozdanie z działalności Zakładu Historii Medycyny za rok 1945/1946,

Archiwum Uniwersytetu Jagiellońskiego, sygn. SIII-34, k. 20, Sprawozdanie z działalności zakładu historii medycyny Uniwersytetu Jagiellońskiego za rok 1946/1947.

Archiwum Uniwersytetu Jagiellońskiego, sygn. SIII-35.

Bilikiewicz T., Wspomnienia autobiograficzne, „Kwartalnik Historii Nauki i Techniki” 1978, nr 1.

Domosławski Z., Ziembicki Witołd (1874-1950), [w:] Z. Podgórska-Klawe (red.), Słownik biograficzny polskich nauk medycznych XIX $i$ XX w., t. 1, z. 2, Warszawa 1994.

Gryglewski R.W., Historia medycyny jako przedmiot badań $i$ nauczania w krakowskim środowisku uniwersyteckim w latach 1809-1914, Kraków 2015.

http://cybra.lodz.pl/Content/5911/625-644.pdf.

http://www.wiw.pl/wielcy/kwartalnik/BilikiewiczTadeusz_08.asp.

Jastrzębowski Z., Srogosz T., Polska szkoła filozofii medycyny a marksizm, „Medycyna Nowożytna” 1994, z. 1-2.

${ }^{72}$ Ibidem. 
Jankowiak S., Schramm S. (red.), Dzieje Uniwersytetu w Poznaniu w latach 1945-2019, Poznań 2019.

Jeszke J., W poszukiwaniu polskiej historiografii medycznej, Poznań 2000.

Jeszke J., Mity polskiej historiografii nauki, Warszawa 2007.

Konopka S., Zdzistaw Wiktor (1911-1970) historyk medycyny i profesor nefrologii Akademii Medycznej we Wrocławiu, „Archiwum Historii Medycyny" 1970, t. 33, z. 2.

Konopka S., Profesor dr Adam Wrzosek, redaktor i wydawca Archiwum Historii i Filozofii Medycyny w latach 1924-1949, „Archiwum Historii Medycyny" 1975, t. 38, z. 1.

Konstańczak S., Wkład Adama Wrzoska w odbudowe szkolnictwa medycznego w Poznaniu, „Akta Medicorum Polonorum” 2020, z. 1.

Kos J.B., Pochwycone w sieć pamięci, [w:] B.J. Kos (red.), Ocalić od zapomnienia: pamiętniki, wspomnienia i szkice biograficzne dolnoślaskich lekarzy, Wrocław 2015.

Kujawski R., Tadeusz Bilikiewicz - psychoterapeuta w dwudziestoleciu międzywojennym, cz. 2. Onejroanaliza, „Psychiatria i Psychoterapia" 2017, nr 4.

Machaliński Z., Wokót genezy i początków Akademii Medycznej w Gdańsku, Gdańsk 1998.

Musielak M., Adam Wrzosek, [w:] M. Musielak, J. Zamojski (red.), Polska szkoła filozofii medycyny. Przedstawiciele i wybrane teksty źródłowe, Poznań 2010.

Paciorek M., Działalność Komisji Historii Nauk Medycznych przy Radzie Naukowej Ministerstwa Zdrowia w latach 1952-1956 w świetle dokumentów Archiwów Akt Nowych, „Medycyna Nowożytna” 2019, z. 1.

Pankiewicz H., Profesor dr farmacji Robert Rembielinski 1894-1975, „Archiwum Historii Medycyny” 1976, t. 39, z. 1.

Sieńkowski E., Dzieje Akademii Medycznej w Gdańsku 1945-1995, Gdańsk 1995.

Skulimowski M., Doc. dr med. Zbigniew Kukulski (1908-1971), „Archiwum Historii Medycyny” 1972, z. 1/2, http://cybra.lodz.pl/Content/7060/334_ForumNr_10ForumNr10.pdf.

Wieczorkiewicz B., Moje pótwiecze, [w:] E. Drobnik, J. Wunderlich (red.), Pamiętniki lekarzy, Warszawa 2004. 